Research Papers, part of a Special Feature on Conservation of Grassland Birds: Causes and Consequences of Population Declines

\title{
Breeding Biology of Grassland Birds in Western New York: Conservation and Management Implications
}

\section{Biologie de la reproduction des oiseaux de prairies dans l'ouest de l'état de New York : répercussions en matière de conservation et de gestion}

\author{
Christopher J. Norment $^{1}$, Michael C. Runge ${ }^{2}$, and Michael R. Morgan ${ }^{1,3}$
}

\begin{abstract}
Declining grassland breeding bird populations have led to increased efforts to assess habitat quality, typically by estimating density or relative abundance. Because some grassland habitats may function as ecological traps, a more appropriate metric for determining quality may be breeding success. Between 1994 and 2003 we gathered data on the nest fates of Eastern Meadowlarks (Sturnella magna), Bobolinks (Dolichonyx oryzivorous), and Savannah Sparrows (Passerculus sandwichensis) in a series of fallow fields and pastures/hayfields in western New York State. We calculated daily survival probabilities using the Mayfield method, and used the logistic-exposure method to model effects of predictor variables on nest success. Nest survival probabilities were 0.464 for Eastern Meadowlarks $(n=26), 0.483$ for Bobolinks $(n$ $=91)$, and 0.585 for Savannah Sparrows $(n=152)$. Fledge dates for first clutches ranged between 14 June and 23 July. Only one obligate grassland bird nest was parasitized by Brown-headed Cowbirds (Molothrus ater), for an overall brood parasitism rate of 0.004 . Logistic-exposure models indicated that daily nest survival probabilities were higher in pastures/hayfields than in fallow fields. Our results, and those from other studies in the Northeast, suggest that properly managed cool season grassland habitats in the region may not act as ecological traps, and that obligate grassland birds in the region may have greater nest survival probabilities, and lower rates of Brown-headed Cowbird parasitism, than in many parts of the Midwest.
\end{abstract}

RÉSUMÉ. En raison de la diminution des populations d'oiseaux de prairies, les efforts visant à évaluer la qualité de l'habitat sont de plus en plus importants. Ces évaluations sont généralement effectuées par l'estimation de la densité ou de l'abondance relative. Étant donné que certains habitats de prairie peuvent se révéler des pièges écologiques, le succès de reproduction peut être une mesure plus appropriée pour déterminer la qualité des habitats. Entre 1994 et 2003, nous avons récolté des données sur le destin des nids de la Sturnelle des prés (Sturnella magna), du Goglu des prés (Dolichonyx oryzivorous) et du Bruant des prés (Passerculus sandwichensis) dans plusieurs champs en jachère, pâturages et champs de foin dans l'ouest de l'état de New York. Nous avons calculé le taux de survie quotidien à l'aide de la méthode de Mayfield. Nous avons également utilisé la méthode logistique d'exposition afin de modéliser les effets des variables explicatives sur le succès de reproduction. Le taux de survie quotidien s'élevait à $0,464 \%$ pour la Sturnelle des prés $(n=26)$, à $0,483 \%$ pour le Goglu des prés $(n=91)$ et à $0,585 \%$ pour le Bruant des prés $(n=152)$. Les dates d'envol pour les premières couvées étaient comprises entre le 14 juin et le 23 juillet. Un seul nid d'une des espèces d'oiseaux spécialistes des prairies a été parasité par des Vachers à tête brune (Molothrus ater) pour un taux global de parasitisme des couvées de 0,004\%. Les modèles logistiques d'exposition ont indiqué que le taux de survie quotidien était plus élevé dans les pâturages et les champs de foin que dans les champs en jachère. Nos résultats, ainsi que ceux provenant d'autres études menées dans le Nord-est, suggèrent que, dans cette région, les habitats de prairie (graminées de saison ${ }^{1}$ Department of Environmental Science and Biology, The College at
Brockport, State University of New York, ${ }^{2}$ U.S. Geological Survey, ${ }^{3}$ New
York State Department of Environmental Conservation

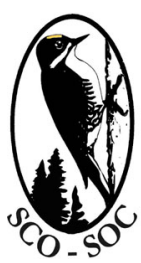

Sponsored by the Society of Canadian Ornithologists and Bird Studies Canada Parrainée par la Société des ornithologistes du Canada et Études d'oiseaux Canada

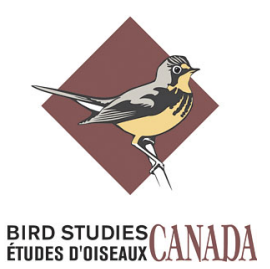


fraîche) gérés correctement pendant la saison hivernale ne constituent pas des pièges écologiques et que, par rapport à d'autres régions du Midwest, le taux de reproduction des oiseaux spécialistes des prairies serait supérieur, et le taux de parasitisme de Vacher à tête brune serait inférieur.

Key Words: Bobolink; breeding biology; conservation; Eastern Meadowlark; grassland birds; management; Northeast; Savannah Sparrow.

\section{INTRODUCTION}

Populations of many obligate grassland birds in North America have declined significantly during the last 40 yr (Sauer et al. 2008). Although population trends of many breeding birds vary across regions, the declining trend for grassland birds is consistent across much of North America, including the Northeast (Peterjohn and Sauer 1999, Murphy 2003, Sauer et al. 2008). Declining trends for many grassland birds in the Northeast, defined here as New York and the six New England states, has stimulated much research because a better understanding of the ecology of these species will assist in developing management plans (Vickery and Herkert 2001). Much of the early, managementoriented research on grassland bird ecology in the Northeast focused on aspects of habitat selection, including effects of grassland area and vegetation structure and composition on grassland bird abundance (e.g., Bollinger and Gavin 1992, Vickery et al. 1994, Bollinger 1995, Smith 1997, Norment et al. 1999).

Although habitat selection studies provide valuable information for managers interested in enhancing grassland bird populations, there are several reasons why more data on the breeding biology of grassland birds in the Northeast also are important. First, there is a general need for more data on grassland bird breeding productivity across North America (Vickery and Herkert 2001), along with comparative studies from different regions (Winter et al. 2006). Second, density and abundance may be misleading indicators of habitat quality (Van Horne 1983, Hobbs and Hanley 1990, Vickery et al. 1992a, Walk and Warner 2000; but see Bock and Jones 2004), because habitats with large numbers of grassland birds may function as population sinks (sensu Pulliam 1988, Vickery and Herkert 2001) or ecological traps (Best 1986, Bollinger et al. 1990, Misenhelter and Rotenberry 2000, Schlaepfer et al. 2002). Third, factors affecting grassland bird density may be different from those affecting nesting success (Hughes et al. 1999, Winter and Faaborg 1999, Davis 2003, Winter et al. 2006).

From 1994 to 2003 we collected breeding biology data for grassland birds at Iroquois National Wildlife Refuge in western New York State. We focused on the three common obligate grassland birds (sensu Vickery et al. 1999) in the study area: Bobolink (Dolichonyx oryzivorous), Eastern Meadowlark (Sturnella magna), and Savannah Sparrow (Passerculus sandwichensis). Because Breeding Bird Survey data indicate that these species have declined in the Northeast since the 1960s (Sauer et al. 2008), one objective of our study was to provide data to evaluate management activities on the refuge and surrounding area. A second objective was to compare our data on nesting success of obligate grassland breeding birds from a site near the periphery of their range, i.e., in the Northeast, to published data from the Midwest, considered to be the center of distribution in North America for most grassland species and their habitats (Vickery et al. 1999). Data from our study supplement those from other studies of obligate grassland bird breeding biology in the Northeast (Bollinger and Gavin 1992, Vickery et al. 1992a, Wells 1997, Balent and Norment 2003, Perlut et al. 2006, Perlut et al. 2008); together, these provide a context for evaluating efforts to conserve obligate grassland breeding birds in the region.

\section{STUDY AREA AND METHODS}

\section{Study site}

We began our study in May 1994 at Iroquois National Wildlife Refuge (NWR) and the contiguous New York State Department of Environmental Conservation Tonawanda and Oak Orchard Wildlife Management Areas (WMAs; $43^{\circ}$ $08^{\prime} \mathrm{N}, 78^{\circ} 23^{\prime} \mathrm{W}$ ), approximately $65 \mathrm{~km}$ west of 
Rochester, New York, in the Great Lakes Plain ecozone of New York (Andrle and Carroll 1988). More than 1,000 ha of potential upland habitat for grassland birds exist in the Iroquois NWR, Oak Orchard and Tonawanda WMA complex. This habitat includes fields managed as warm season grasslands dominated by switchgrass (Panicum virgatum), old fields with a grass/forb/shrub mix, fallow farm fields, and pastures/hayfields (Norment et al. 1999), interspersed in a landscape matrix of wetlands, croplands, and hardwood forests. Common grasses in old fields, fallow farm fields, hayfields and pastures included the cool season species timothy (Phleum pratense), orchard grass (Dactylis glomerata), redtop (Agrostis alba), and smooth brome (Bromus inermis). Common forbs included goldenrod (Solidago spp.), wild carrot (Daucus carota), milkweed (Asclepias spp.), and birds-foot trefoil (Lotus corniculatus). Nine fields were included in the study, ranging from 5 ha to 98 ha; these fields were classified as either pastures/ hayfields $(n=3)$ or fallow fields $(n=6)$. Pastures/ hayfields were disturbed by mowing, haying, or light grazing after 1 August and the cessation of grassland bird breeding, generally on an annual basis, whereas fallow fields were not disturbed by management-related activities during the study. Sample size and range of field areas was constrained by the number of patches maintained as grassland in the study area. Fallow fields had a higher proportion of forbs and shrubs than did pastures/ hayfields (C. J. Norment, unpublished data).

\section{Field methods}

We conducted nest searches by flushing females or following an incubating female or adult carrying food to the nest. Number of eggs and/or nestlings, and unhatched eggs were recorded, along with any evidence of brood parasitism by Brown-headed Cowbirds (Molothrus ater). The most intensive nest searches and monitoring occurred in 1994, 1995, 1996, 2002, and 2003; we found smaller numbers of nests from 1997-2001. We marked most known nests with a small piece of flagging placed $\sim 5 \mathrm{~m}$ from the nest, and checked them at two to three $\mathrm{d}$ intervals, as suggested by Hazler (2004), until nestlings were close to fledging, at which time we checked them at one d intervals. We attempted to minimize disturbance around nests by approaching them from different directions on consecutive visits. Successful fledging was most often, in about $80 \%$ of the cases, determined by the presence of attendant parents in the vicinity of the nest.

\section{Statistical analyses}

We calculated two metrics of nesting success: apparent nest success, and the daily probability of nest survival. Although apparent nest success, i.e., the proportion of known nests surviving to fledging, generally overestimates true nesting success (Johnson and Shaffer 1990, Jehle et al. 2004, Perlut et al. 2006), it has been commonly reported in the literature and we present it for comparisons with studies from the Midwest. We calculated daily survival probabilities using the program MAYFIELD (Hines 2002), based on all nest records for each species. The probability of nest survival then was calculated by raising daily survival rates by the power of average lengths of the nesting cycle reported in the Birds of North America accounts: $23 \mathrm{~d}$ for the Savannah Sparrow (Wheelwright and Rising 2008), 24.5 d for Eastern Meadowlarks (Lanyon 1995), and $23 \mathrm{~d}$ for Bobolinks (Martin and Gavin 1995). Although limitations of the Mayfield method have been noted (Jehle et al. 2004, Shaffer 2004), it generally gives results similar to those of the Stanley (2004) method, program MARK (Dinsmore at al. 2002), and the logistic exposure method (Jehle et al. 2004, Winter et al. 2004), and again is useful for comparisons with other studies.

We also used the logistic-exposure method (Shaffer 2004) to model effects of predictor variables on nest success. The response variable in the logisticexposure method is nest success or failure over individual periods of observation, i.e., times between visits; predictor variables included the factors species, i.e., Bobolink, Eastern Meadowlark, and Savannah Sparrow, year, and habitat type, i.e., fallow field and hayfield/pasture, while field area was treated as a continuous covariate. We created a series of 38 candidate models that included all subsets of predictors from the most complex model, and compared them using Akaike's Information Criterion (AIC) corrected for small sample size $\left(\mathrm{AIC}_{\mathrm{c}}\right.$; Burnham and Anderson 2002). Models were ranked according to $\triangle \mathrm{AIC}_{\mathrm{c}}$, the difference between each model and the model with the lowest $\mathrm{AIC}_{\mathrm{c}}$ value; we also calculated $\mathrm{AIC}_{\mathrm{c}}$ weights $\left(w_{i}\right)$ for each model, which assist in assessing the evidence favoring a model (Burnham and Anderson 2002). The most complex model that we evaluated 
Table 1. Breeding biology data for obligate grassland breeding birds at Iroquois National Wildlife Refuge, 1994-2003. Daily survival probabilities were calculated using the Mayfield method. Values are mean \pm SE; sample sizes are given in ( ). BOBO = Bobolink, EAME = Eastern Meadowlark, SAVS = Savannah Sparrow.

\begin{tabular}{llllll}
\hline \hline Species & $\begin{array}{l}\text { Clutch initiation } \\
\text { date }^{\dagger}\end{array}$ & Fledge date & $\begin{array}{l}\text { Range, fledge } \\
\text { dates }\end{array}$ & $\begin{array}{l}\text { Apparent nest } \\
\text { success }\end{array}$ & $\begin{array}{l}\text { Daily survival } \\
\text { probability }\end{array}$ \\
\hline BOBO & $25.5 \pm 1.08(74)$ & $53.3 \pm 1.05(55)$ & 14 June -24 July & $0.659(91)$ & $0.969 \pm 0.006(91)$ \\
EAME & $14.1 \pm 1.95(23)$ & $41.9 \pm 2.26(18)$ & 30 May - 3 July & $0.654(26)$ & $0.969 \pm 0.011(26)$ \\
SAVS & $24.4 \pm 1.07(128)$ & $47.4 \pm 1.05(109)$ & 30 May - 23 July & $0.743(152)$ & $0.977 \pm 0.004(152)$
\end{tabular}

$\dagger$ Dates are given as days from 1 May, with 1 May $=1$.

included all predictors as main effects, plus three two-way interactions (habitat*species, species* area, and habitat*area) and one three-way interaction (species*habitat*area). Interactions included in the initial model were specified a priori, based on our understanding of grassland bird breeding biology and our "system" (Burnham and Anderson 2002). No two-, three-, or four-way interactions with year were included in our models, because of rank deficiencies. Summary statistics are reported as mean $\pm 1 \mathrm{SE}$, unless otherwise noted.

\section{RESULTS}

We determined nest fates for 269 obligate grassland bird nests at Iroquois NWR between 1994-2003. Apparent nest success was $0.659(n=91)$ for Bobolinks, $0.654(n=26)$ for Eastern Meadowlarks, and $0.743(n=152)$ for Savannah Sparrows. Mean daily survival probabilities ranged from 0.969 for Bobolinks to 0.977 for Savannah Sparrows (Table $1)$; these generated nest survival probabilities of 0.483 for Bobolinks, 0.464 for Eastern Meadowlarks, and 0.585 for Savannah Sparrows. Clutch size averaged 5.20 \pm 0.09 for Bobolinks, 4.76 \pm 0.12 for Eastern Meadowlarks, and $4.20 \pm 0.06$ for Savannah Sparrows; hatchabilities (sensu Koenig 1982) ranged from 0.909 for Bobolinks to 0.936 for Eastern Meadowlarks (Table 2). Average initiation date for first clutches was earliest for Eastern Meadowlarks (14 May) and latest for Bobolinks (25 May; Table 1). Range of known fledge dates for first clutches spanned a period between 14 June and 24 July for the three species
(Table 1). We found only one obligate grassland bird nest, that of a Savannah Sparrow, parasitized by a Brown-headed Cowbird, for an overall brood parasitism rate of 0.004 ( $n=269$ nests).

We evaluated 38 models relating obligate grassland bird nest success to the predictors species, habitat, area, and year (Table 3). The best model included only the predictors habitat and area, while the only other model with a $\Delta \mathrm{AIC}_{\mathrm{c}}$ value $<2.0$ included habitat, area, and the habitat-area interaction (Table 3 ). Neither species nor year had significant effects in any of the 38 models that we evaluated. For the best model, daily nest survival probabilities were higher in pasture/hayfield habitat than in fallow fields (Fig. 1). For this model, logistic-exposure predictions across the range of possible areas $(0-$ 100 ha) indicated that daily nest survival probabilities remained almost constant across area for pasture/hayfields, but decreased for fallow fields (Fig. 1).

\section{DISCUSSION}

\section{Comparisons with grassland bird breeding biology in the Midwest}

Our results indicate that obligate grassland birds at Iroquois NWR have potentially high breeding productivity, relative to many populations in the Midwest. Clutch sizes for Eastern Meadowlarks, Bobolinks, and Savannah Sparrows were equivalent to, or greater than, values reported from the upper Midwest (Lanyon 1995, Martin and Gavin 1995, 
Table 2. Mean clutch size and clutch-size distribution for grassland birds at Iroquois National Wildlife Refuge, 1994-2003.

\begin{tabular}{|c|c|c|c|c|c|c|c|c|c|}
\hline \multirow[b]{2}{*}{ Species } & \multirow[b]{2}{*}{$n$} & \multicolumn{6}{|c|}{ Clutch Size } & \multirow[b]{2}{*}{ Mean \pm SE } & \multirow[b]{2}{*}{ Hatchability $(n)$} \\
\hline & & 2 & 3 & 4 & 5 & 6 & 7 & & \\
\hline Bobolink & 81 & 1 & 0 & 10 & 42 & 27 & 1 & $5.20 \pm 0.085$ & $0.909(350)$ \\
\hline Eastern Meadowlark & 25 & 0 & 0 & 8 & 15 & 2 & 0 & $4.76 \pm 0.119$ & $0.936(94)$ \\
\hline Savannah Sparrow & 128 & 1 & 10 & 80 & 36 & 1 & 0 & $4.20 \pm 0.055$ & $0.932(439)$ \\
\hline
\end{tabular}

Winter et al. 2004, Wheelwright and Rising 2008). Hatchability, defined as the proportion of eggs surviving to the end of incubation that hatch (Koenig 1982), is another aspect of these species' basic breeding biology that supports our contention. Hatchability may be negatively affected by a variety of social and ecological factors, but values for Eastern Meadowlarks, Bobolinks, and Savannah Sparrows were greater than that predicted for a latitude of $43^{\circ} \mathrm{N}$ (Koenig 1982).

Basic breeding biology traits such as clutch size are important in assessing habitat suitability for grassland breeding birds. However, breeding productivity is a more useful indication of habitat quality (Van Horne 1983, Hobbs and Hanley 1990, Vickery et al. 1992a, Walk and Warner 2000), and by all measures, obligate grassland breeding birds at Iroquois NWR are "doing better" than many populations in the Midwest (Table 4). For Eastern Meadowlarks, Mayfield nest survival probabilities in the Midwest ranged from $0.03-0.59$, whereas apparent nest success rates were about 0.30 (Table $4)$; corresponding values for Iroquois NWR were 0.464 and 0.654. For Bobolinks, Mayfield nest survival probabilities in the Midwest ranged from $0.14-0.534$, with one apparent nest success rate of 0.482; corresponding values for Iroquois NWR were 0.483 and 0.659 . Finally, Mayfield nest survival probabilities in the Midwest for Savannah Sparrows ranged from $0.019-0.388$, with one apparent nest success rate of 0.584 (Table 4); corresponding values for our study were 0.585 and 0.743. Brown-headed Cowbird parasitism rates, $\mathrm{i}$. e., proportion of nests parasitized, are variable across the Midwest (Shaffer et al. 2003), but are often much higher than found in our study. Only
0.004 of all known grassland bird nests were parasitized at Iroquois NWR, wherease midwestern parasitism rates ranged between $0.02-0.70$ for Eastern Meadowlarks, $0.11-0.50$ for Bobolinks, and $0-0.45$ for Savannah Sparrows (Table 4; see also Shaffer et al. 2003).

There are relatively few data on the breeding biology of obligate grassland birds from other areas in New York and New England, although all available data support the comparison between our data and those for the Midwest. Mayfield nest survival probabilities were 0.527 for Bobolinks and 0.585 for Savannah Sparrows in cool season grasslands at Fort Drum, New York, with no cowbird parasitism in 113 nests (Bolsinger et al. 1999). In a series of Vermont hayfields and pastures, nest success for obligate grassland birds varied substantially across a series of grazing and mowing treatments, although apparent survival rates and nest survival probabilities (logistic exposure method) averaged 0.64 and 0.46 for Bobolinks and 0.55 and 0.40 for Savannah Sparrows, respectively, in fields that were not disturbed until after 1 August (Perlut et al. 2006). Martin and Gavin (1995) reported an apparent nest success rate for Bobolinks in New York of 0.545 , with no Brown-head Cowbird parasitism, whereas brood parasitism rates for Savannah Sparrows in New Brunswick and Nova Scotia were 0.012 and 0.013 , respectively (Wheelwright and Rising 2008). Finally, Vickery et al. (1992a) reported an overall apparent nest success rate of 0.54 for a small $(n=39)$ sample of nests from a sandplain grassland in Maine.

Our logistic-exposure results suggested that nest survival was higher in hayfields/pastures than in 
Table 3. Model selection results for daily nest survival for obligate grassland breeding birds, Iroquois National Wildlife Refuge. The top 11 out of 38 models are shown (those with AICc weights, $w_{i}$, greater than 0.01). The models are described by indicating which main effects and interactions were included (Sp $=$ species, $\mathrm{Hab}=$ habitat, $\mathrm{A}=$ area, $\mathrm{Yr}=$ year), and the number of parameters, $k$, they contained.

\begin{tabular}{|c|c|c|c|c|c|c|c|c|c|c|c|}
\hline \multicolumn{8}{|c|}{ Model } & \multirow[t]{2}{*}{$k$} & \multirow[t]{2}{*}{$\mathrm{AIC}_{\mathrm{c}}$} & \multirow[t]{2}{*}{$\Delta \mathrm{AIC}_{\mathrm{c}}$} & \multirow[t]{2}{*}{$w$} \\
\hline $\mathrm{Sp}$ & $\mathrm{Hab}$ & A & Yr & $\mathrm{Sp} * \mathrm{Hab}$ & $\mathrm{Sp}^{*} \mathrm{~A}$ & $\mathrm{Hab}^{*} \mathrm{~A}$ & $\mathrm{Sp} * \mathrm{Hab} * \mathrm{Yr}$ & & & & \\
\hline & $\mathrm{X}$ & $\mathrm{X}$ & & & & & & 3 & 629.007 & 0.000 & 0.421 \\
\hline & $X$ & $X$ & & & & $X$ & & 4 & 630.526 & 1.519 & 0.197 \\
\hline & $\mathrm{X}$ & & & & & & & 2 & 632.135 & 3.128 & 0.088 \\
\hline $\mathrm{X}$ & $\mathrm{X}$ & $\mathrm{X}$ & & & & & & 5 & 632.594 & 3.586 & 0.070 \\
\hline $\mathrm{X}$ & $\mathrm{X}$ & $\mathrm{X}$ & & & $\mathrm{X}$ & & & 7 & 633.171 & 4.163 & 0.053 \\
\hline $\mathrm{X}$ & $\mathrm{X}$ & $\mathrm{X}$ & & $\mathrm{X}$ & $\mathrm{X}$ & & & 9 & 633.978 & 4.970 & 0.035 \\
\hline $\mathrm{X}$ & $X$ & $\mathrm{X}$ & & & & $X$ & & 6 & 634.160 & 5.153 & 0.032 \\
\hline $\mathrm{X}$ & $X$ & $X$ & & & $\mathrm{X}$ & $X$ & & 8 & 635.176 & 6.168 & 0.019 \\
\hline $\mathrm{X}$ & $\mathrm{X}$ & & & & & & & 4 & 635.553 & 6.545 & 0.016 \\
\hline $\mathrm{X}$ & $X$ & $\mathrm{X}$ & & $\mathrm{X}$ & $\mathrm{X}$ & $\mathrm{X}$ & & 10 & 635.740 & 6.732 & 0.015 \\
\hline $\mathrm{X}$ & $X$ & $\mathrm{X}$ & & $X$ & & & & 7 & 636.273 & 7.266 & 0.011 \\
\hline
\end{tabular}

fallow fields. Area had little effect on nest survival probabilities in pastures/hayfields, but had a negative effect on survival probabilities in fallow agricultural fields (Fig. 1). This result is surprising, given the generally positive effect of field area on grassland bird breeding productivity metrics (Johnson and Temple 1990, Winter and Faaborg 1999, Balent and Norment 2003, Herkert et al. 2003, Bollinger and Gavin 2004, Ribic et al. 2009; but see Skagen et al. 2005, Davis et al. 2006, Winter et al. 2006). However, the negative area effect for fallow fields may be partially explained by a lower daily survival probability for the small set of nests $(n=$ 10) located in the largest fallow field (69 ha) included in our study (Fig. 1). In turn, the lower survival probability in this field may have been related to the presence of transmission lines, which were absent from other fields in the study; these lines bisected the field and offered perches for potential nest predators, such as American Crows (Corvus brachyrhynchos; C. J. Norment, personal observation).

\section{Management and conservation implications}

Although our data on obligate grassland bird breeding biology are from only one area in western New York, they, along with data from other parts of the Northeast, may have several wider management and conservation implications. First, they suggest that at least some grasslands in the region may not act as ecological traps (Schlaepfer et al. 2002), and potentially may provide more productive breeding habitat than in many midwestern areas, at least those not managed directly for obligate grassland breeding birds. High productivity for obligate grassland breeding birds 
Fig. 1. Daily survival probabilities for obligate grassland bird nests at Iroquois National Wildlife Refuge in fallow fields (solid line, closed circles) and pasture/hayfields (dashed line, open circles). The lines are the predictions from the top logistic exposure model, with $95 \%$ confidence intervals. The circles are field-specific Mayfield estimates. The sixth fallow field, with area 40 ha and estimated daily survival rate of 0 , is not shown because the sample size, 1 nest, was so small.

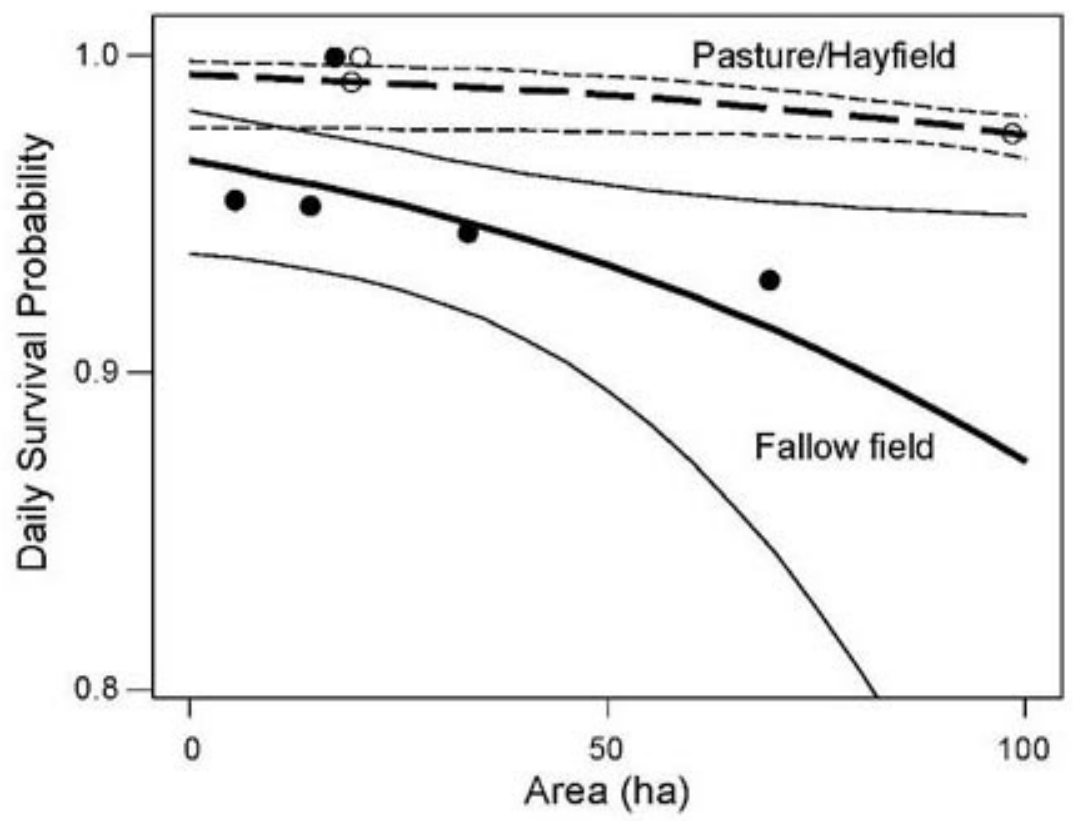

in the Northeast may be due to proper management of disturbance in selected sites, and reduced levels of predation and brood parasitism. In terms of disturbance, none of our study sites were mowed, hayed, or grazed until after 1 August, by which time grassland breeding birds had fledged young (Table 1 ). In contrast, early haying had strong negative effects on grassland bird productivity (Perlut et al. 2006) and survival (Perlut et al. 2008) in Vermont; nest success of Bobolinks in New York (Bollinger et al. 1990); and Eastern Meadowlarks in Illinois (Roseberry and Klimstra 1970).

Nest predation is a critical demographic parameter for declining grassland songbirds (Fletcher et al. 2006), and control of multiple species of predators from large grassland tracts may increase the productivity of prairie-nesting ducks (Greenwood and Sovada 1996). Although we know of no data with which to compare predator abundance in midwestern and northeastern grasslands, several indirect pieces of evidence suggest that predation may be relatively light, at least in large, properly managed grasslands in the region. First, predation rates on artificial nests placed in grasslands at Iroquois NWR were highest at field-forest boundaries (Ardizzone and Norment 1999), and in smaller grasslands (Windig 2006), while Bobolink nests in interior grassland habitat, $>100 \mathrm{~m}$ from a wooded edge, had higher survival rates than nests in edge habitat (Bollinger and Gavin 2004). Second, Mayfield nest survival probabilities for Grasshopper Sparrows (Ammodramus savannarum) in New York were much lower (0.24) in small grasslands $\leq$ 13 ha (Balent and Norment 2003) than in large grasslands (240 - 650 ha) in Massachusetts (0.624; Jones 2000); in both study sites, predation appeared to be the main cause of nest failure (Jones 2000; C. J. Norment, unpublished data). Third, nest predation by mammals in at least one northeastern grassland appears to be mostly incidental, and not because of active searching for songbird nests (Vickery et al. 1992b). 
Table 4. Breeding biology data for Eastern Meadowlarks, Bobolinks, and Savannah Sparrows from midwestern North America and the current study (boldface).

\begin{tabular}{|c|c|c|c|c|c|}
\hline Species & $\begin{array}{l}\text { State/ } \\
\text { Province }\end{array}$ & $\begin{array}{l}\text { Apparent nest } \\
\text { success }\end{array}$ & $\begin{array}{c}\text { Mayfield nest } \\
\text { survival probability }\end{array}$ & $\begin{array}{c}\text { Cowbird } \\
\text { parasitism } \\
\text { (proportion) }\end{array}$ & Source \\
\hline
\end{tabular}

Eastern Meadowlark

\section{NY}

IL

KS

IL

KS

KS

NE

WI

IL, KS, MO

MO

$\mathrm{KS}, \mathrm{OK}$

Bobolink

$\begin{array}{lcc}\text { NY } & \mathbf{0 . 6 5 9} & \mathbf{0 . 4 8 3} \\ \text { WI } & & 0.534 \\ \text { ND, MN } & 0.14-0.16 \\ \text { IA } & 0.482 & 0.294 \\ \text { ND, MN } & 0.207 \\ \text { MB } & \\ \text { ND } & \\ \text { ND } & \end{array}$

Savannah Sparrow
0.743

ND

$\mathrm{MN}$

MN

MB

SK

MN, ND

0.584
0.654

0.305

0.33

$$
\begin{gathered}
0.03-0.59 \\
0.195
\end{gathered}
$$

0.095-0.176

0.585

0.155

0.019

0.338

0.07

0.227

0.314
0.245

0.00

0.34

0.18

0.11

0.50

0.25

0.11

0.006

0.02

0.70

$0.50 \quad$ Fleischer 1986

$0.16 \quad$ Hergenrader 1962

$0.16 \quad$ Lanyon 1957

0-0.53 Herkert et al. 2003

Winter and Faaborg 1999

Rahmig et al. 2008

\section{Current study}

Johnson and Temple 1990

Koford 1999

Fletcher et al. 2006

Winter et al. 2004

Davis and Sealey 2000

Koford et al. 2000

Granfors et al. 2001

\section{Current study}

Koford 1999

Koford 1999

$0.37 \quad$ Johnson and Temple 1990

0.32 Davis and Seeley 2000

0-0.45 Davis 2003

$0.05 \quad$ Winter et al. 2004 
Although reasons for generally lower rates of predation on grassland bird nests in the Northeast may be difficult to discern, there is a clear relationship between rates of Brown-headed Cowbird abundance and brood parasitism for obligate grassland breeding birds in the Midwest and Northeast. In the Midwest, rates of cowbird parasitism on grassland bird nests are correlated with cowbird abundance at both the regional (Herkert et al. 2003) and local scales (Jensen and Cully 2005). Given that cowbird populations are much higher in the Midwest than in the Northeast (Peterjohn et al. 2000, Sauer et al. 2008), and that cowbird parasitism declines with distance from the Midwest (Chace et al. 2005), we would expect that brood parasitism rates from our study site, and other areas in the region, would be low. Although a demographic study of Dickcissels (Spiza americana) and Bobolinks in Iowa indicated that reduction of nest parasitism from the observed rate of about 0.18 would be insufficient to ensure stable populations of either species (Fletcher et al. 2006), nest parasitism rates may be much higher than 0.18 in parts of the Midwest (Table 4), and models suggest that high rates of brood parasitism can suppress seasonal fecundity more than predation (Gryzbowski and Pease 2000).

A final point in regards to management is that in our study, nesting productivity was high in habitat patches dominated by introduced cool season grasses, as at Fort Drum, New York (Bolsinger et al. 1999), and in Vermont hayfields not cut until after 1 August (Perlut et al. 2006). Abundance of most northeastern obligate grassland birds also is high in cool season grasslands with relatively low cover (Bollinger 1995, Vickery and Dunwiddie 1997, Norment et al. 1999, Runge et al. 2004). Grassland birds in the Midwest also do well in Conservation Reserve Program (CRP) fields enrolled in the CPI (cool season grasses and legumes) option (Best et al. 1997, Delisle and Savidge 1997, McCoy et al. 2001b). These data lead us to question the tendency of grassland restoration or establishment efforts in the Northeast to emphasize warm season grasses such as switchgrass (Panicum virgatum), Indian grass (Sorghastrum nutans), and big bluestem (Andropogon gerardii; Dickerson et al. 1998; see also Norment 2002; National Resouces Conservation Service, unpublished data). The rationale for this policy may be that most naturally occurring grasslands in the Northeast, which were limited primarily to maritime areas and sand plains, were dominated by warm season grasses (Niering and Dreyer 1989, Dunwiddie et al. 1997, Mehrhoff 1997); there also is a concern that human-created grasslands may provide less optimal habitat for grassland breeding birds than do naturally occurring grasslands (Herkert et al. 1993, Haas and Titus 1998, Askins 2000). However, many obligate grassland birds in North America depend upon artificial habitats (Askins et al. 2007), and abundance of obligate grassland birds in warm season grasslands in the region with tall, dense vegetation, which occurs frequently, may be low (Norment et al. 1999, Runge et al. 2004; see also McCoy et al. 2001a; C. J. Norment, M. Norris, and $\mathrm{S}$. Isaacs, unpublished report). Thus, available data tend to suggest that vegetation structure is more important than composition for obligate grassland birds in the Northeast. If managers in the region want to promote both grassland bird populations and native grasses in appropriate habitats, then cool season grasses native to the Northeast, such as Canada wildrye (Elymus canadensis), may be planted in place of warm season species, or planting mixtures should contain both native warm and cool season grasses.

In conclusion, although our data are from a single study area in western New York, they do suggest, along with data from other studies in the region, that large, existing grassland habitats in the region, if managed properly, can provide high-quality breeding habitat for a suite of obligate grassland birds that are declining across much of North America. Finally, maintenance of these habitats as grasslands will not only benefit grassland birds, but will also meet other important conservation goals, such as maintenance of open, attractive cultural landscapes, and regional biodiversity (Askins 2000, Foster 2002).

Responses to this article can be read online at: http://www.ace-eco.org/vol5/iss2/art3/responses/

\section{Acknowledgments:}

We thank the many field assistants who provided invaluable and dedicated help in finding nests and collecting data. Funding support for the project was provided by the American Museum of Natural History's Frank M. Chapman Memorial Fund; Buffalo Ornithological Society; College at Brockport, State University of New York; New York 
Department of Environmental Conservation; U.S. Fish and Wildlife Service (USFWS) Region 5; USFWS Iroquois National Wildlife Refuge, and $U$. S. Geological Survey.

\section{LITERATURE CITED}

Andrle, R. F., and J. R. Carroll. 1988. The atlas of breeding birds in New York State. Cornell University Press, Ithaca, New York, USA.

Ardizzone, C. D., and C. J. Norment. 1999. Experimental analysis of nest predation in a New York grassland: effects of habitat and nest distribution. Studies in Avian Biology 19:122-127.

Askins, R. A. 2000. Restoring North America's birds: lessons from landscape ecology. Yale University Press, New Haven, Connecticut, USA.

Askins, R. A., F. Chávez-Ramírez, B. C. Dale, C. A. Haas, J. R. Herkert, F. L. Knopf, and P. D. Vickery. 2007. Conservation of grassland birds in North America: understanding ecological processes in different regions. Ornithological Monographs 64:1-46.

Balent, K. L., and C. J. Norment. 2003. Demographic characteristics of a Grasshopper Sparrow population in a highly fragmented landscape of western New York State. Journal of Field Ornithology 74:341-348.

Best, L. B. 1986. Conservation tillage: ecological traps for nesting birds? Wildlife Society Bulletin 14:308-317.

Best, L. B., H. Campa, III, K. E. Kemp, R. J. Robel, M. R. Ryan, J. A. Savidge, H. P. Weeks, Jr., and S. R. Winterstein. 1997. Bird abundance and nesting in CRP fields and cropland in the Midwest: a regional approach. Wildlife Society Bulletin 25:864-877.

Bock, C. E., and Z. F. Jones. 2004. Avian habitat evaluation: should counting birds count? Frontiers in Ecology and the Environment 2:403-410.

Bollinger, E. K. 1995. Successional changes and habitat selection in hayfield communities. Auk 112:720-730.
Bollinger, E. K., P. B. Bollinger, and T. A. Gavin. 1990. Effects of haycropping on eastern populations of the Bobolink. Wildlife Society Bulletin 18: $142-150$.

Bollinger, E. K., and T. A. Gavin. 1992. Eastern Bobolink populations: ecology and conservation in an agricultural landscape. Pages 497-506 in J. M. Hagan, III, and D. W. Johnston, editors. Ecology and conservation of neotropical migrant landbirds. Smithsonian Institution Press, Washington, D.C., USA.

Bollinger, E. K., and T. A. Gavin. 2004. Responses of nesting Bobolinks (Dolichonyx oryzivorous) to habitat edges. Auk 121:767-776.

Bolsinger, J. S., S. J. Joule, and R. R. LeClerc. 1999. Grassland bird communities on Fort Drum, New York. Natural/Cultural Resources Branch, Environmental Division of Public Works, Fort Drum, New York.

Burnham, K.P., and D. R. Anderson. 2002. Model selection and multimodel inference: a practical information-theoretic approach. Second edition. Springer-Verlag. New York, New York, USA.

Chace, J. F., C. Farmer, R. Winfree, D. R. Curson, W. E. Jensen, C. B. Goguen, and S. K. Robinson. 2005. Cowbird (Molothrus spp.) ecology: a review of factors influencing distribution and abundance of Cowbirds across spatial scales. Ornithological Monographs 57:45-70.

Davis, S. K. 2003. Nesting ecology of mixed-grass prairie songbirds in southern Saskatchewan. Wilson Bulletin 115:119-130.

Davis, S. K., R. M. Brigham, T. L. Shaffer, and P. C. James. 2006. Mixed-grass prairie passerines exhibit weak and variable responses to patch size. Auk 123:807-821.

Davis, S. K., and S. G. Sealy. 2000. Cowbird parasitism and nest predation in fragmented grasslands of Southwestern Manitoba. Pages 220-228 in J. N. M. Smith, T. L. Cook, S. I. Rothstein, S. K. Robinson, and S. G. Sealy, editors. Ecology and management of cowbirds and their hosts: studies in the conservation of North American passerine birds. University of Texas Press, Austin, Texas, USA. 
Delisle, J. M., and J. A. Savidge. 1997. Avian use and vegetation characteristics of Conservation Reserve Program fields. Journal of Wildlife Management 61:318-325.

Dickerson, J. D., B. Wark, D. Burgdorf, R. Maher, T. Bush, B. Poole, and C. Miller. 1998. Vegetating with native grasses in northeastern North America: a manual. U.S. Department of Agriculture, National Resources Conservation Service, Plant Materials Program, and Ducks Unlimited Canada, Syracuse, New York, USA.

Dinsmore, S. J., G. C. White, and F. L. Knopf. 2002. Advanced techniques for modeling avian nest survival. Ecology 83:3476-3488.

Dunwiddie, P. W., W. A. Patterson, III, J. L. Rudnicky, and R. E. Zaremba. 1997. Vegetation management in coastal grasslands on Nantucket Island, Massachusetts: effects of burning and mowing from 1982 to 1993. Pages 85-98 in P. D. Vickery, and P. W. Dunwiddie, editors. Grasslands of northeastern North America. Massachusetts Audubon Society, Lincoln, Massachusetts, USA.

Elliot, P. F. 1978. Cowbird parasitism in the Kansas tallgrass prairie. Auk 95:161-167.

Fleischer, R. C. 1986. Brood parasitism by Brownheaded Cowbirds in a simple host community in eastern Kansas. Kansas Ornithological Society Bulletin 37:21-29.

Fletcher, R. J., Jr., R. R. Koford, and D. A. Seaman. 2006. Critical demographic parameters for declining songbirds breeding in restored grasslands. Journal of Wildlife Management 70:145-157.

Foster, D. R. 2002. Thoreau's country: a historicalecological perspective on conservation in the New England landscape. Journal of Biogeography 29:1537-1555.

Granfors, D. A., K. E. Church, and L. M. Smith. 1996. Eastern Meadowlarks in rangelands and Conservation Reserve Program fields in Kansas. Journal of Field Ornithology 67:222-235.

Granfors, D. A., P. J. Pietz, and L. A. Joyal. 2001. Frequency of egg and nestling destruction by female Brown-headed Cowbirds at grassland nests. The Auk 118:765-769.
Greenwood, R.J., and M.A.Sovada. 1996. Prairie duck populations and predation management. Transactions North American Wildlife and Natural Resources Conference 61:31-42.

Grzybowski, J. A., and C. M. Pease. 2000. Comparing the relative effects of brood parasitism and nest predation on seasonal fecundity in passerine birds. Pages 145-155 in J. N. M. Smith, T. L. Cook, S. I. Rothstein, S. K. Robinson, and S. G. Sealy, editors. Ecology and management of cowbirds and their hosts: studies in the conservation of North American passerine birds. University of Texas Press, Austin, Texas, USA.

Haas, C., and R. Titus. 1998. Grassland birds not nesting in non-native grasses. Abstract from the Annual Meeting of the Ecological Society of America, Baltimore, Maryland, August 1-6, 1998. In Supplement to the bulletin of the Ecological Society of America. Ecological Society of America, Washington, D.C., USA.

Hazler, K. R. 2004. Mayfield logistic regression: a practical approach for analysis of nest survival. Auk 121:707-716.

Hergenrader, G. L. 1962. The incidence of nest parasitism by Brown-Headed Cowbird (Molothrus ater) on roadside nesting birds in Nebraska. Auk 79:85-88.

Herkert, J. R., D. L. Reinking, D. A. Wiedenfeld, M. Winter, J. L. Zimmerman, W. E. Jensen, E. J. Finck, R. R. Koford, D. H. Wolfe, S. K. Sherrod, M. A. Jenkins, J. Faaborg, and S. K. Robinson. 2003. Effects of prairie fragmentation on the nest success of breeding birds in the midcontinental United States. Conservation Biology 17:587-594.

Herkert, J. R., R. E. Szafoni, V. M. Kleen, and J. E. Schwegman. 1993. Habitat establishment, enhancement, and management for forest and grassland birds in Illinois. Division of Natural Heritage, Illinois Department of Conservation, Natural Heritage Publication 1, Springfield, Illinois, USA.

Hines, J. E. 2002. Program MAYFIELD to compute estimates of daily survival from nest visitation data. USGS Patuxent Wildlife Research Center, Laurel, Maryland, USA [online] URL: http ://www.mbr-pwrc.usgs.gov/software.html. 
Hobbs, N. T., and T. A. Hanley. 1990. Habitat evaluation: do use/availability data reflect carrying capacity? Journal of Wildlife Management 54:515-522.

Hughes, J. P., R. J. Robel, K. E. Kemp, and J. L. Zimmerman. 1999. Effects of habitat on Dickcissel abundance and nest success in Conservation Reserve Program fields in Kansas. Journal of Wildlife Management 63:523-529.

Jehle, G., A. A. Yackel Adams, J. A. Savidge, and S. K. Skagen. 2004. Nest survival estimation: a review of alternatives to the Mayfield estimator. Condor 106:472-484.

Jensen, W. E., and J. F. Cully,Jr. 2005. Geographic variation in Brown-Headed Cowbird (Molothrus ater) parasitism on Dickcissels (Spiza americana) in great plains tallgrass prairie. Auk 122:648-660.

Johnson, D. H., and T. L. Shaffer. 1990. Estimating nest success: when Mayfield wins. Auk 107:595-600.

Johnson, R. G., and S. A. Temple. 1990. Nest predation and brood parasitism of tallgrass prairie birds. Journal of Wildlife Management 54:106-111.

Jones, A. L. 2000. Grasshopper Sparrow (Ammodramus savannarum) metapopulation dynamics and conservation strategies in Massachusetts. Thesis. University of Massachusetts Amherst, Amherst, Massachusetts, USA.

Koenig, W. D. 1982. Ecological and social factors affecting hatchability of eggs. Auk 99:526-536.

Koford, R. R. 1999. Density and fledging success of grassland birds in Conservation Reserve Program fields in North Dakota and west-central Minnesota. Studies in Avian Biology 19:187-195.

Koford, R. R., B. S. Bowen, J. T. Lokemoen, and A. D. Kruse. 2000. Cowbird parasitism in grassland and cropland in the northern Great Plains. Pages 229-235 in J. N. M. Smith, T. L. Cook, S. I. Rothstein, S. K. Robinson, and S. G. Sealy, editors. Ecology and management of cowbirds and their hosts: studies in the conservation of North American passerine birds. University of Texas Press, Austin, Texas, USA.
Lanyon, W. E. 1957. The comparative biology of the Meadowlarks (Sturnella) in Wisconsin. Pages 1-47 in Publications of the Nuttall Ornithological Club. Nuttall Ornithological Club, Cambridge, Massachusetts, USA.

Lanyon, W. E. 1995. Eastern Meadowlark (Sturnella magna). From A. Poole, editor. The birds of North America online. Cornell Lab of Ornithology, Ithaca, New York, USA. [online] URL: http://bna.birds.cornell.edu/bna/species/160

Martin, S. G., and T. A. Gavin. 1995. Bobolink (Dolichonyx oryzivorous). From A. Poole, editor. The birds of North America online. Cornell Lab of Ornithology, Ithaca, New York, USA. [online] URL: http://bna.birds.cornell.edu/bna/species/176

McCoy, T. D., E. W. Kurzejeski, L. W. Burger, Jr., and M. R. Ryan. 2001 $a$. Effects of conservation practice, mowing, and temporal changes on vegetation structure on CRP fields in northern Missouri. Wildlife Society Bulletin 29:979-987.

McCoy, T. D., M. R. Ryan, and L. W. Burger, Jr. 2001b. Grassland bird conservation: CP1 vs. CP2 plantings in Conservation Reserve Program fields in Missouri. American Midland Naturalist 145:1-17.

Mehrhoff, L. J. 1997. Thoughts on the biogeography of grassland plants in New England. Pages 15-23 in P. D. Vickery, and P. W. Dunwiddie, editors. Grasslands of Northeastern NorthAmerica. Massachusetts Audubon Society, Lincoln, Massachusetts, USA.

Misenhelter, M. D., and J. T. Rotenberry. 2000. Choices and consequences of habitat occupancy and nest site selection in Sage Sparrows. Ecology 81:2892-2901.

Murphy, M. T. 2003. Avian population trends within the evolving agricultural landscape of eastern and central United States. Auk 120:20-34.

Niering, W. A., and G. D. Dreyer. 1989. Effects of prescribed burning on Andropogon scoparius in postglacial grasslands in Connecticut. American Midland Naturalist 122:88-102. 
Norment, C. J. 2002. On grassland bird conservation in the Northeast. Auk 119:271-279.

Norment, C. J., C. D. Ardizzone, and K. Hartman. 1999. Habitat relations and breeding biology of grassland birds in New York. Studies in Avian Biology 19:112-121.

Perlut, N. G., A. M. Strong, T. M. Donovan, and N. J. Buckley. 2006. Grassland songbirds in a dynamic management landscape: behavioral responses and management strategies. Ecological Applications 16:2235-2247.

Perlut, N. G., A. M. Strong, T. M. Donovan, and N. J. Buckley. 2008. Grassland songbird survival and recruitment in agricultural landscapes: implications for source-sink demography. Ecology 89:1941-1952.

Peterjohn, B. G., and J. R. Sauer. 1999. Population status of North American grassland birds from the North American Breeding Bird Survey, 1966-1996. Studies in Avian Biology 19:27-44.

Peterjohn, B. G., J. R. Sauer, and S. Schwarz. 2000. Temporal and geographic patterns in population trends of Brown-Headed Cowbirds. Pages 21-34 in J. N. M. Smith, T. L. Cook, S. I. Rothstein, S. K. Robinson, and S. G. Sealy, editors. Ecology and management of cowbirds and their hosts: studies in the conservation of North American passerine birds. University of Texas Press, Austin, Texas, USA.

Pulliam, H. R. 1988. Sources, sinks, and population regulation. American Naturalist 132:652-661.

Rahmig, C. J., W. E. Jensen, and K. A. With. 2008. Grassland bird responses to land management in the largest remaining tallgrass prairie. Conservation Biology 23:420-432.

Ribic, C. A., R. R. Koford, J. R. Herkert, D. H. Johnson, N. D. Niemuth, D. E. Naugle, K. K. Bakker, D. W. Sample, and R. B. Renfrew. 2009. Area sensitivity in North American grassland birds: patterns and processes. Auk 126:233-244.

Robinson, S. K., J. P. Hoover, and J. R. Herkert. 2000. Cowbird parasitism in a fragmented landscape: effects of tract size, habitat, and abundance of cowbirds and hosts. Pages 281-297 in
J. N. M. Smith, T. L. Cook, S. I. Rothstein, S. K. Robinson, and S. G. Sealy, editors. Ecology and management of cowbirds and their hosts: studies in the conservation of North American passerine birds. University of Texas Press, Austin, Texas, USA.

Roseberry, J. L., and W. D. Klimstra. 1970. The nesting ecology and reproductive performance of the Eastern Meadowlark. Wilson Bulletin 82:243-267.

Runge, M. C., L. R. Mitchell, and C. J . Norment. 2004. Grassland bird breeding use of managed grasslands on National Wildlife Refuges within Region 5 of the U.S. Fish and Wildlife Service. USGS Patuxent Wildlife Research Center, Laurel, Maryland, USA.

Sauer, J. R., J. E. Hines, and J. Fallon. 2008. The North American breeding bird survey, results and analysis 1966-2007. Version 5.15.2008. USGS Patuxent Wildlife Research Center, Laurel, Maryland, USA. [online] URL: http://www.mbr-pw rc.usgs.gov/bbs/.

Schlaepfer, M. A., M. C. Runge, and P. W. Sherman. 2002. Ecological and evolutionary traps. Trends in Ecology and Evolution 17:474-480.

Shaffer, J. A., C. M. Goldade, M. F. Dinkins, D. H. Johnson, L. D. Igl, and B. R. Euliss. 2003. Brown-headed Cowbirds in grasslands: their habitats, hosts, and response to management. Prairie Naturalist 35:145-186.

Shaffer, T.L. 2004. A unified approach to analyzing nest success. Auk 121:526-540.

Skagen, S. K., A. A. Y. Adams, and R. D. Adams. 2005. Nest survival relative to patch size in a highly fragmented shortgrass prairie landscape. Wilson Bulletin 117:23-34.

Smith, C. R. 1997. Use of public grazing lands by Henslow's Sparrows, Grasshopper Sparrows, and associated grassland birds in central New York State. Pages 171-186 in P. D. Vickery, and P. W. Dunwiddie, editors. Grasslands of northeastern North America. Massachusetts Audubon Society, Lincoln, Massachusetts, USA.

Stanley, T. R. 2004. Estimating stage-specific daily survival probabilities of nests when nest age is unknown. Auk 121:134-147. 
Van Horne, B. 1983. Density as a misleading indicator of habitat quality. Journal of Wildlife Management 47:893-901.

Vickery, P. D., and P. W. Dunwiddie, editors. 1997. Grasslands of northeastern North America. Massachusetts Audubon Society, Lincoln, Massachusetts, USA.

Vickery, P. D., and J. R. Herkert. 2001. Recent advances in grassland bird research: where do we go from here? Auk 118:11-15.

Vickery, P. D., M. L. Hunter, Jr., and S. M. Melvin. 1994. Effects of habitat area on the distribution of grassland birds in Maine. Conservation Biology 8:1087-1097.

Vickery, P. D., M. L. Hunter, Jr., and J. V. Wells. 1992a. Is density an indicator of breeding success? Auk 109:706-710.

Vickery, P. D., M. L. Hunter, Jr., and J. V. Wells. $1992 b$. Evidence of incidental nest predation and its effects on nests of threatened grassland birds. Oikos 63:281-288.

Vickery, P. D., P. L. Tubaro, J. M. Cardosa Da Silva, B. G. Peterjohn, J. R. Herkert, and R. B. Cavalcanti. 1999. Conservation of grassland birds in the western hemisphere. Studies in Avian Biology 19:2-26.

Walk, J. W., and R. E. Warner. 2000. Grassland management for the conservation of songbirds in the Midwestern USA. Biological Conservation 94:165-172.

Wells, J. V. 1997. Population viability analysis for Maine Grasshopper Sparrows. Pages 153-170 in P. D. Vickery, and P. W. Dunwiddie, editors. Grasslands of northeastern North America. Massachusetts Audubon Society, Lincoln, Massachusetts, USA.

Wheelwright, N. T., and J. D. Rising. 2008. Savannah Sparrow (Passerculus sandwichensis). From A. Poole, editor. The birds of North America online. Cornell Lab of Ornithology, Ithaca, New York, USA. [online] URL: http://bna.birds.cornell. edu/bna/species/045.
Windig,S. 2006. Grassland birdnest predation and artificial nest use. Thesis. State University of New York Collage at Brockport, Brockport, New York, USA.

Winter, M., and J. Faaborg. 1999. Patterns of area sensitivity in grassland-nesting birds. Conservation Biology 13:1424-1436.

Winter, M., D. H. Johnson, J. A. Shaffer, T. M. Donovan, and W. D. Svedarsky. 2006. Patch size and landscape effects on density and nesting success of grassland birds. Journal of Wildlife Management 70:158-172.

Winter, M., D. H. Johnson, J. A. Shaffer, and W. D. Svedarsky. 2004. Nesting biology of three grassland passerines in the Northern Tallgrass Prairie. Wilson Bulletin 116:211-223. 